\title{
Quality Assurance in Gifted Education
}

\author{
Rabee Alqahtani ${ }^{1{ }^{* *},}$ Narentheren Kaliappen ${ }^{2}$ \\ ${ }^{1}$ Faculty of Education, University of Wollongong, New South Wales, Australia \\ ${ }^{2}$ School of International Studies (SoIS), College of Law, Government \& International Studies (UUM COLGIS), Universiti Utara \\ Malaysia, Malaysia
}

Received June 22, 2020; Revised July 26, 2020; Accepted October 24, 2020

\section{Cite This Paper in the following Citation Styles}

(a): [1] Rabee Alqahtani, Narentheren Kaliappen, "Quality Assurance in Gifted Education," Universal Journal of Educational Research, Vol. 8, No. 11, pp. 5137-5150, 2020. DOI: 10.13189/ujer.2020.081113.

(b): Rabee Alqahtani, Narentheren Kaliappen (2020). Quality Assurance in Gifted Education. Universal Journal of Educational Research, 8(11), 5137-5150. DOI: 10.13189/ujer.2020.081113.

Copyright $\bigcirc 2020$ by authors, all rights reserved. Authors agree that this article remains permanently open access under the terms of the Creative Commons Attribution License 4.0 International License

\begin{abstract}
The aim of this review is to consider recent research related to the quality of gifted education. The first six webpages of Google Scholar were searched to collect over 80 papers. PRISMA flow diagram was used for screening to finally select 58 papers for this review. Gifted and Talented Education (GATE) is a package of instructional practices, processes and theories designed to help high performing students, and to enhance their capabilities academically. This study reviews the quality standards of gifted education in certain countries. One research comparing 21 European countries using the international framework for gifted education is included in the study. The conceptual and theoretical aspects of the training are mostly related to cognitive and non-cognitive aspects of learning. A fiercely debated topic is whether gifted education should be separate or included in a common programme. Both sides use high-quality principles and educational frameworks (ICAP, CDL) to strengthen their viewpoints. Another aspect of the study is whether minorities are proportionately represented in such programmes. Methods of service delivery play an important role in ensuring the quality of gifted education and the principals and teachers of the respective institutions are the chief players. Suggestions are given to ensure quality of gifted education, to countries which need improvements in the existing gifted education programmes and to countries which do not have such programmes given. The implication of this study is that it is possible to differentiate exceptionally talented students and ensure that they are not slowed down by conventional teaching programmes or curricula. Add-on programmes can be designed for these students to help them learn faster and prepare them for more advanced levels. Also, including
\end{abstract}

gifted children without any classification of race or creed is possible and signals inclusivity, which is good for the discipline in general.

Keywords Gifted Education, Talents, Elite Bias, Intelligence, Minority Underrepresentation

\section{Introduction}

Gifted children are talented or exceptionally brilliant children who have IQs above 125 as per the common perception. Purdue Engineering (2020) noted that gifted children are usually profiled as a "mini-Einstein" or a "little professor." These children are stereotyped with having glasses, a pocket protector, and are often portrayed as contemplating scientific discoveries and inventions. Their grasping power is better than their peers and finds all subjects easy to understand. While the label hurts these children, it excludes those who are otherwise talented.

One early official definition of gifted children provided by the U.S. Commissioner of Education under Public Law 91-230, section 806, was cited by Marland in his report to the U.S. Congress in 1972. The definition states that gifted and talented children have outstanding abilities and are capable of exemplary performance. Their selection is made by teachers who are qualified for identifying giftedness. These children are provided specifically designed educational programmes or services much more than what is provided to regular students. This sharpens their skills further and enables them to realise their contribution to self and society (Marland, 1972). 
The need to go beyond the foundations of gifted and talented education was soon recognised. For example, Gardener's theory of multiple intelligence (Gardner, 1983; 1999; 2004) - as cited by Almeida, et al. (2010), recognises eight types of intelligences. There had been some federal actions before and after 1972, the latest of which was the Jacob K. Javits Gifted and Talented Children and Youth Education Act of 1987, which was listed by Jolly and Robins (2016). Federal funding for gifted education was erratic from 1974 to 2015 , although there was a spurt in funding during 2013-2015, which peaked in 2015. U.S. states were poorly equipped with the required personnel or funding.

The National Association for Gifted Children USA characterises giftedness in the following manner (NAGC, 2019):

- Gifted and talented children are capable of performing at higher levels in comparison to their peers of the same age and experience. They perform better in similar environments in one or more domains.

- A modification to their educational experience is required to improve their potential and sharpen their skills.

- Gifted students belong to diverse backgrounds and come from various economic strata and racial, ethnic and cultural populations.

- The correct learning opportunities which help them to increase their potential have to be prioritized.

- Any correction required to rectify learning and processing disorders should be done early and include professional intervention and accommodation.

- The social and emotional development of gifted students should be monitored through proper support and guidance.

- Any services required based on their unique needs have to be provided on demand.

There is a tendency to categorise gifted children by their IQs. One such classification is provided by Bainbridge (2019). Accordingly, depending on the type of test used, gifted children are classified as:

- Mildly gifted - 115 to 129 ,

- Moderately gifted - 130 to 144 ,

- Highly gifted - 145 to 159

- Exceptionally gifted- 160 to 179

- Profoundly gifted - 180 and above

Bainbridge (2019) also lists other methods to identify gifted children by exceptional talent, high achievement, potential, and high sensitivity. However, IQ exams only measure certain skills, and many gifted children possess skills which are not included in these tests. The problems with using IQ tests to assess the mental capacities of children were discussed in Oxford Learning (2015). IQ tests provide specific standardized scores, and hence are an attractive way to identify children requiring different instruction. While the extremes may be valid, it is not always easy to differentiate in that manner. IQ tests normally measure the capability of the child to comprehend words, sentences and grammar, visual-spatial reasoning, memorising power and processing speed to arrive at a comprehensive score to calculate the level of giftedness.

Three very popular tests are Wechsler Intelligence Scale for Children - Fifth Edition (WISC-V), the Stanford-Binet Intelligence Scale - Fifth Edition, and the Differential Ability Scales - Second Edition (DAS-II). The Wechsler Intelligence Scale for Children - Fifth Edition (WISC-V) is used for children of age 6 to 16 and provides a full-scale IQ score as well as five-factor scores for different functional dimensions. The Stanford-Binet test was one of the earliest IQ tests and can be used for all ages, even beyond 80. It was used to estimate the IQs of famous people past and present. As the first versions of tests did not cover all ranges of functional skills, new versions were introduced over time. This fifth edition covers fluid reasoning, knowledge, quantitative reasoning, visual-spatial processing and working memory.

DAS-II is used for measuring cognitive ability, abstract reasoning, and critical thinking. It can be used for children of 2 to 17 years. The test is used to measure the capability of the child in inductive reasoning, verbal and spatial ability. Some problems with IQ tests are: 1) Gifted children develop asynchronously, making the scores obtained at one stage invalid at another stage, 2) Distraction, anxiety, and stress during tests can affect the scoring, 3) Labelling children based on single scores can lead to children developing lower self-confidence and avoid challenges as they think that their label is adequate justification for their special status. Scores are used to evaluate the child's education rather than their learning style. IQ tests narrow down to specific capabilities and do not provide a holistic picture. Multi-dimensional tests and assessments are more useful than IQ tests for children to focus on improvements and for teachers to address gaps in their teaching methods.

\section{Methodology}

In the following sections, a systematic review of available literature related to the quality of gifted education and the factors contributing to quality are presented. Being a systematic review, only databases and search engines were sourced for this paper. In the process of data collection and selection of papers for this review, the PRISMA framework was used. The results of the screening procedure are provided in the Appendix.

The Google Scholar search yielded 60 papers from six web pages. Another 30 useful papers were collected from cross-references within the selected articles. A total of 90 papers were collected, of which 21 were excluded as they were not related to the focus of this study. From the remaining 69 papers, 11 papers were excluded as five of 
them were repetitions of the same findings, and six papers were sections of unavailable books. The remaining 58 papers were included in this review. Seven of the reviewed articles were summarized in the introduction, and 51 were used for this review.

\section{Results}

\section{National institutions on gifted education and research}

Most of the above discussions focused on the U.S., with one exception from the UK. The status of other countries also is important. Gifted education in European countries was reviewed by Boettger (2015). In the UK, the concept was introduced in 1944 when a new Schools Act considered talented children studying in the newly created grammar schools. This led to elitist tendencies, and hence, many of the grammar schools were replaced by comprehensive schools. Now, gifted education is a part of the general education approach rather than a separate entity. About 5 to $10 \%$ of students are considered talented. Scotland follows the inclusive policy established in the U.K. Gifted children are provided with opportunities to develop their talents outside schools. Teachers decide who are gifted students and they often resort to grouping students based on their abilities in order to provide a holistic education. The National Association for Gifted Children (1967), National Association for Able Children in Education (NACE, 1983), and the National Academy for Gifted and Talented Youth (NAGTY) (2002), of Warwick University were some organisations dedicated to the development of gifted children. However, NAGTY was closed in 2010 despite a good evaluation by the Department of Education.

In Austria, gifted education was specifically mentioned in national legislation in 1962. A policy of allowing gifted children to skip classes in the 1970's was replaced with an integrated education approach in the 1990's. An Austrian Research and Support Centre for the Gifted and Talented were established in 1999 for the education of gifted children and support for their families and teachers. A general decree on the promotion of giftedness and talent was issued by the Ministry for Education in 2009, asking all schools to develop potentials of gifted and talented children. This was a significant deviation from the previous policies with no specific attention to the education of gifted children.

The status of gifted education and research in India was reviewed by Roy (2017). Research on gifted education in India was confined to the creativity aspect over the last 50 years. Gifted children are recognised at home as well as at schools. However, there had been very few formal education programmes to develop their giftedness. There is inadequate information or database about policies, programmes, practices, and outcomes of gifted education in the country. The National Association of Gifted Children estimates 3-5\% of its children as gifted. There are many institutions connected with gifted education and research in India. The oldest talent search institution was the state-funded Jagadis Bose National Science Talent Search (JBNSTS), Kolkata, established in 1958. It is also connected with Science, Technology, Engineering, and Mathematics (STEM). Jnana Prabodhini Institute of Psychology (JPIP) Pune was established in 1969 with similar aims and purposes. The National Council for Educational Research and Training (NCERT) has a programme of National Talent Search Examination (NTSE) since 1963. The Department of Science \& Technology (DST) has a project funding programme for young scientists since the last 15 years, The Homi Bhabha Centre for Science Education conducts Olympiad programs in Mathematics, Physics, Chemistry, Biology, and Astronomy since 1974. Tribal Mensa Nurturing Program (TMNP) Pune was started in 2002 with 50 schools all over Maharashtra for gifted tribal children. It is India's first Associated European Talent Centre. Its close associate, Kaveri Gifted Education Centre, Pune was started in 2014 with similar purposes. Delhi University has an Innovation centre. The National Institute of Advanced Studies (NIAS) project was started in 2010, and the National Association of Gifted Education, India originated in 2012, and has a website to promote gifted children through PRODIGY (Promoting India's Gifted Young). Many published and unpublished works of researchers in these institutes were reviewed by the author.

The UK national strategy for enhancing the quality of gifted education was discussed by Dracup (2003). The strategies consist of intensive localised programmes like excellence initiatives at cities, clusters and other dimensions and providing a programme to challenge excellence among the students; a GATE A suited to regional needs as part of the Gifted and Talented Education London Challenge. Opportunities for parents, students and the teachers at the national level in the new Academy for Gifted and Talented Youth were also given. These strategies cover gifted children of the age group 5-19 years. There is a greater focus on ability than achievement, which means more attention is given to underachievers. The terms "Gifted" and "Talented" are differentiated. Gifted are those excelling in academics and talented are those who excel in other fields like sports, arts etc. There may be some allrounders who have both in different degrees. Among the total students, about 5 to $10 \%$ have been marked as gifted and talented for school level and national level strategies.

The extent to which the interns of Summer Enrichment Workshop (SEW) of the University of Alabama are equipped to teach gifted students was measured using mixed approach by Newman, Gregg, and Dantzler (2009). The workshop was beneficial to the interns as the significant improvement was noted in their knowledge and preparation to teach higher-order thinking skills. 
Quantitative results were validated through Qualitative support. SEW had positive effects on teaching competencies of the interns for ensuring quality in gifted education. The need for the adequacy of funding for gifted education sufficiently and equitably was highlighted by Baker and McIntire (2003) citing the examples of Florida and Virginia as models, which could be emulated.

Similar variations in funding and their utilisation patterns among US states were also reported by Baker and Friedman-Nimz (2004). The findings were from an exploratory qualitative case study of ten government secondary schools of grades 7-12 in New South Wales(NSW), Australia. Schools with some selective gifted education were more likely to follow state policy and provide distinctive gifted programmes. It was noted that if the school principals were following the policies set, their schools were more likely to provide adequate resource support and professional development for the qualified teachers. However, in certain cases, the principals may not have the means to support the teachers in this manner (Long, Barnett, \& Rogers, 2015), even if they felt the need to comply with the policy mandate. Although there are many limitations and inadequacies in the case of National/State Leadership Training Institute on the Gifted and Talented (N/S-LTI-G/T), its effect on programmes for improving quality of gifted education is widely prevalent across many states of USA (Jolly, 2014). Shaughnessy and Persson (2009) noted that trends in neurological research findings, enrichment through IT, writing skills and communication, creativity, mentoring, and counselling have contributed to gifted education, there is need for increased focus on educational efficiency, critical and higher-order thinking to have a significant improvement in the quality of general education and especially for Gifted Education. Considerable scope exists for development in legislation and genetics in future. Gifted education is perceived as a set of special curricula based on constructivist principles of content, process, and product applied to the specific learning environment in which many different instructional strategies are used as per the programs for gifted learners. This contention may be merely a justification for considering gifted education as a separate variety. In this connection, Tomlinson (997) proposed a model for advanced learners useful for both instructional practices and research on the topic. Lapan (1989) observed that the parameters used for identifying gifted youths could be used for evaluation of the quality of gifted education programmes also. Such parameters should cover the ability for innovation, help stimulate the students intellectually, should be comprehensive to cover a wide variety of topics and encourage divergence.

\section{Conceptual and theoretical aspects of gifted education}

Some issues related to gifted education itself were raised by Gallagher (1996). The first question was on the very existence of giftedness. The second issue was on the difficulties of identifying such students and providing qualitatively differentiated programs and services. Thirdly, there is a morality issue in offering such programs or services to a set of privileged students at the exclusion of a large majority of others. It is necessary to align the philosophy and the definition of giftedness, the method of identification of gifted children, the program models and evaluation practices. This is necessary for better service deliveries and clarity of goals (Jarvis \& Henderson, 2014). How creativity (which applies to gifted people) was explainable using the theories of Vygotsky and Piaget was discussed by Stoltz et al (2015). Vygotsky theorised that creativity is an inherent human characteristic. Creativity expresses itself through consciousness, thought and language. It is the highest expression of subjectivity (Vygotsky, 2010). According to Piagetian theory, creativity is a mystery to Piaget; it manifests in the construction of knowledge structures and cognitive functioning. Teachers need to facilitate the development of creativity among gifted children. Various dimensions of gifted education concept were examined by Sapon-Shevin (1996). In gifted education programs, the focus is on giving exceptional education for students with zero failure tolerance. Consequently, it leaves the general educational system as such, preventing any critiquing. Teachers, students, and society face different consequences due to gifted education programs. Some of the important related issues are silence followed by the pain of gifted students, suitable differentiation methods, fear of abandonment of gifted students, excellence/equity debate and scope for large scale reforms. In a similar line of discussions, Callahan (1996) wondered whether gifted education is a healthy practice, a necessary evil or sedition. Being a supporter of gifted education, the author approached the subject in terms of the triumphs and disappointments. Contenting that the current approaches of gifted education are based on erroneous presumptions, Ziegler and Phillipson (2012) put forward a systemic theory as the correct approach. The erroneous presumption is that the components of giftedness need to be understood for developing exceptionality. In a systemic approach, on the other hand, exceptionality is understood based on interactions between cognitive and non-cognitive factors. Actiotope Model of Giftedness was used for understanding exceptionality. Abilities of gifted people have different trajectories of varying start, peak and end. Both society and the gifted individual have mutual responsibility. Society needs to provide opportunities for effective utilisation of these talents for mutual benefits. The psychosocial goal of eminence needs to be targeted in gifted education. These views were expressed by Subotnik, Olszewski-Kubilius, and C (2011). Three paradigms (gifted child, talent development and differentiation) were discussed in connection with gifted education. These paradigms were compared and contrasted. The paradigms consisted of 
answering the questions what, why, who and how in three different ways. This $4 \mathrm{~W}$ framework can be useful in research and practice of gifted education. The extension of the sociocultural theory to gifted education was probed and proved as useful for improving teaching practices in gifted education by McGlonn-Nelson (2005). Another set of three paradigm shifts were analysed by Lo and Porath (2017). Among the three paradigms and their characters first is demystification, meaning giftedness and is considered as manifested marvels, identification of giftedness, the second paradigm, meaning measurable predictions. Moreover, the third is transactions meaning effectuation of human possibilities. All the three have been existing in an overlapping manner rather than one following the other.

\section{Separate or common education for gifted?}

The debate between experts on whether gifted children should be educated in the common stream or identified separately with special education programmes for their faster academic progress was highlighted by Hockett (2009) According to the views of the author, as long as gifted children are in the common stream, the quality of their education is reduced. Because of this view, seven principles of high-quality general education were contrasted with four principles of high-quality gifted education as follows-

High-quality general education can be classified based on the seven principles

- Principle 1: Concepts should be used for designing, organising and implementation of the Curriculum for High-Quality General Education

- Principle 2: Ideas, Principles and skills essential to the respective disciplines should form the basis for High-Quality General Education Curriculum.

- Principle 3: Flexibility in responding to Student Differences should be the hallmark of High-Quality General Education

- Principle 4: High-Quality General Education Curriculum should be designed to develop the student's expertise by imparting discipline-based skills. Expertise should be progressively developed as per the grade levels using Cognitive and Metacognitive processes.

- Principle 5: One of the chief aims of High-Quality General Education Curriculum should be to emphasize student outcomes, focussing in particular, on the Goal of Deep Understanding.

- Principle 6: High-Quality General Education Curriculum should be designed in such a manner as to engage the students with relevant topics at all times.

- Principle 7: High-Quality General Education Curriculum should be an integrated approach between deep knowledge of the relevant subject and with a focus on the specifics

Apart from the above, there are four other high-quality principles for gifted education as below:

- Principle 1: A conceptual approach is used to Organise or explore content which is as per the required skill set and with an integrative capability in High-Quality Curriculum for Gifted learners.

- Principle 2: A very advanced level of understanding, which is beyond the ordinary curriculum in schools, is pursued by the learners in High-Quality Curriculum for Gifted learners. More emphasis is on dealing with ideas than events, with complex subjects delving into deep knowledge and at the same time focussing on specifics.

- Principle 3: High-Quality Curriculum for Gifted Learners makes the students use processes and materials akin to those used by the expert in their respective field, disciplinarian or a professional who has established himself in that subject.

- Principle 4: High-Quality Curriculum for Gifted Learners prioritises on problem-solving, products and performances that relate to real-life issues and have results which help transform the students to be better.

There are certain overlaps between the two types of quality requirements, and consensus can be found on them as given below-

- High-Quality Curriculum Is Authentic.

- High-Quality Curriculum Is Driven by Meaningful Outcomes.

- High-Quality Curriculum Is Flexible to Account for Student Differences.

- High-Quality Curriculum Is Challenging.

These consensus principles were used in the three models of Integrated Curriculum Model (Van Tassel-Baska, 1986), the Multiple Menu Model (Renzulli, 1988) and the Parallel Curriculum Model (Tomlinson et al., 2002). Although the author discusses the three models at length, no diagrams of the models have been given. The very existence of commonality means the quality of gifted education need not suffer always. Contesting this claim, other possibilities were discussed by Neber (2019) in a review. He pointed out different concepts of improving quality of gifted education. One way is to integrate solutions for gifted education within schools and in classrooms. It also raises the level of the whole educational system. In classrooms, changes are required in the types of learning materials, tasks, learning processes and strategies of students and organisation of teaching itself. Such changes will help to align and reduce the gap among gifted and other students in their teaching and learning especially as the classes are shared among them. In the second method, giftedness is treated as an individual difference variable. Contrary to considering giftedness as an innate character of a person, it is thought as a variable, non-characteristic entity which has a potential to be improved in all students through instructions and not just transform existing giftedness into achievements. Giftedness is only indicative 
of a current state. If these concepts are applied, instead of identifying gifted students first and designing objectives and programmes to fit the students, the reverse process is done. Students are fitted into prefixed objectives and programmes. This method is applicable in a multi-ability context. Those who are gifted will perform better. Thus, there is an innate giftedness potential in every individual, and it expresses outside through proper instructions. Even here, if there are exceptionally brilliant students, specific programmes for them could be added on. If knowledge is considered as fixed, true and unchangeable and being given down by an authority, even gifted students cannot learn by their own thinking and develop their potential through cognitive work. Gifted education has to be monitored for quality, and continuous assessment of intelligence in both cognitive and non-cognitive abilities needs to be done. This will also help to improve the quality of gifted education. Dynamic assessments will show the weaknesses in current programmes in not increasing their intelligence levels. Most successful educational systems exist in countries where schooling and grouping are done based on the idea that learning processes promote abilities and intelligence of gifted students. These concepts make quality improvement of gifted education automatically embedded in the system. Problem-based and other inquiry-based learning has been found to be suitable both in exclusive gifted and mixed ability classes as in both situations; many more students solved the problems compared to traditional classes. Grade skipping can be implemented for the rapid advancement of exceptional students. Integrative frameworks like ICAP (Interactive, Constructive, Active, Passive) and Cooperative Discovery Learning (CDL) have been suggested to ensure the quality of gifted education.

Tomlinson (2005) observed that a quality curriculum for gifted students involves good curriculum and instructions consisting of meaning-making at higher levels and rich content. Appropriate modifications in terms of pacing, degree of challenge required and supported opportunities for developing interests can be made within this framework. Their readiness to learn new things, methods of learning, levels and interests are important determinants in this respect. Eleven curriculum models of gifted education were reviewed by VanTassel-Baska and Brown (2007). The models reviewed were: Stanley model of talent identification, Renzulli Schoolwide enrichment model, Gardener's multiple intelligence model, Purdue three-stage enrichment model for elementary gifted learners (PACE) and Purdue secondary model for gifted and talented youth, Maker matrix, Parallel curriculum model (PCM), Schlichter models for talents unlimited Inc and talents unlimited to secondary power (TU2), Sternberg's triarchic componential model and VanTassel- Baska's integrated curriculum model (ICM). Use of technology enables, enhances, and transforms as the principles can improve the quality of gifted education, according to Chen, Yun Dai, and Zhou (2013). Purcell, Burns, Tomlinson, Imbeau, and
Martin (2002) developed a rubric originally designed to assess the quality of curricular units submitted to the National Association for Gifted Children (NAGC) Curriculum Division's Curriculum Competition annually. Four different unrelated rubrics for improvement in the quality of gifted education were also discussed.

\section{The issue of minority underrepresentation among gifted learners}

Insofar as a certain section of gifted children is excluded from gifted education programmes, the national perspective of gifted education is lowered. This is especially relevant in the case of the USA when one applies the No Child Left Behind Act to gifted education. Many papers were published by Donna Ford on this issue. Some of them are discussed below.

The less the number of minority students in the gifted education programme is a contentious issue. Ford (1998) remarked that issues related to screening and identification, quality of education, personnel and retention are important in this matter. There is the perception that a minority of students are not as gifted as required for special attention, and their inclusion will lower the quality of gifted education, they will not complete the programme due to their socioeconomic problems and teachers are not trained enough to teach them as they have training only in teaching urban majority gifted students. In a later paper, recruitment and retention issues of gifted minority education were focused by Ford, Grantham, and Whitin (2008). Noting that there is consistent underrepresentation of the Black students in gifted education, Ford, Harris III, Tyson, and Trotman (2001) explored the factors responsible for it and identified denial of access to gifted programmes to diverse students due to deficit orientation by educators. This orientation overshadows the capability of the teachers to identify the brightness of minority students. Differences in giftedness are interpreted as deficits, dysfunctions or disadvantages and label them as at-risk candidates in the case of minorities. The importance of cultural and linguistic factors in identifying the gifted children among the minorities through intelligence or other tests was stressed by Ford, Wright, Washington, and Henfield (2016). If these factors are considered, many problems regarding the underrepresentation of minorities in gifted education may be solved. Another solution suggested for the underrepresentation of minority gifted children suggested by (Grantham \& Ford, 1998) was that the principals could monitor the functioning of the educators and evaluate the progress of the students through quality control. Principals can look over the welfare of their staff as that motivates them to do their job better. Presenting a method of estimating underrepresentation and inequity, Ford (2014) opined that the contribution of social inequality, deficit thinking and microaggressions to the inequitable segregated programs like gifted education. 
Underrepresentation is an aspect of achievement gaps. Inequity occurs in schools due to segregation. Underrepresentation occurs more frequently beyond the statistical probability. Underachievers among those with power or social capital with their negative attitudes and beliefs are the reason for this state of affairs. This has been highlighted in many judicial verdicts and proves that the practice of denying access to gifted education based on race does exist. These judicial verdicts used in another paper by Ford and King Jr (2014) to argue that discrimination and prejudice contribute to separate gifted education programmes which are detrimental to the cause of gifted minorities, denying them the opportunity they rightly deserve. The philosophical paradigm of disparate impact was used for establishing that outcome is clearer than intent. Contrary to these arguments, balancing equity with excellence to rectify underrepresentation has been shown to involve various problems (Parr \& Stevens, 2019). In egalitarian societies, the equity principle is at the core. The concept of gifted children poses many issues in these societies. Gifted children are expected to make extraordinary contributions to society when they grow up as adults. The policies on education have to be modified to facilitate the conditions in which these gifted children can foster their abilities. However, such programmes for gifted education sometimes are the cause of inequalities in educational services and equal opportunities for all. The curricula need to be differentiated, considering gifted students. However, when giftedness should be related to the communities to which they apply. Otherwise, there is a risk of excluding gifted children by using an unsuitable model of giftedness. In promoting excellence, gifted education does discriminate with respect to race, the ethnicity and economic disparities among the students.

\section{Gifted education service delivery-Role of principals and teachers}

Needless to say that poor service delivery can affect the quality of gifted education. Some papers dealing with the issue are discussed below. Maintaining high quality of gifted education depends on understanding the inequalities in learning among the students and modifying the service delivery options to suit such needs. While expressing this view, Clarenbach (2007) also said that District administrations should make such gifted education part of their overall goals in education programmes and adequate funds should be provided for it. In this respect, how principals contribute to ensuring gifted education quality in their schools was exemplified through two case studies of rural schools by Lewis, Cruzeiro, and Hall (2007). While declaring the school goals, for communication to the local public, it should be ensured that Gifted education is an essential part of it. Appropriate skills should be used by teachers after understanding the requirements of each individual gifted learner. More the divergence of the gifted from other students, greater is the difficulty of adjustment. Teachers may need special training to handle gifted education. Principals may not have enough time for gifted education. High level of self-efficacy of teachers with gender differences in academic competencies, seniority differences in encouraging creativity among gifted students and age differences in instructional planning competencies were observed by Dinçer (2019), and the author recommended continuous training to upgrade teaching skills of those teaching gifted children in schools. Hudson (2020) did not find any significant differences between gifted and on-gifted students about their perceptions of quality in Advanced International Certificate of Education (AICE) courses offered in a rural high school. Both groups perceived the quality to be reasonably good.

The other side of the argument is that the principals must perform as instructional leaders of the school to enable the teachers to provide quality education to the gifted students correctly. An often ignored aspect is the possibility of gifted education in elevating the quality of general education and bringing the learners to nearer to gifted students and the contribution of Tomlinson and Callahan (1992) focuses in this direction. Providing quality gifted education is a part of quality education for all students defined in the controversial No Child Left Behind Act (P.L. 107-110; Elementary and Secondary Education Amendments of 2001) (Gallagher, 2004) and curriculum treatment processes (VanTassel-Baska, Zuo, Avery, \& Little, 2002). The need for involvement of parents, teachers and concerned citizens for ensuring the quality of gifted education was stressed by Riley and Karnes (1993). The need for online gifted education systems to ensure high-quality curriculum in which basic concepts are superimposed with inquiry learning, challenging and self-directed learning, and issue-based learning, evaluation methods consisting of participation and interaction, assignments and products evaluation, paper-and-pencil tests, and performance or individualized assessments and support for online gifted educational institutions were discussed by Chae (2019).

Recognising the challenge of identifying the various forms of gifted students' learning capacity and their relative efficacy, Munro (2015) proposed the use of an assessment tool based on scenario problem-solving. The method consists of tasks, in which, a real-world situation is described with a problem embedded to it, and it is given for a solution. In tests, 3rd to 6th-grade gifted students fared better than non-gifted students. The level of learning capacity and nature of giftedness (verbal or non-verbal etc) influenced their scores in different types of tasks. Higher capacity for expanded and differentiated knowledge, inferential and divergent thinking were reflected in the solving exercises. Intuitive theory formation, analogistic thinking were also observed in the case of gifted students.

Quality of gifted education varied with the state policy intensities in USA when measured against the seven 
improvement initiatives suggested in the report National Excellence: A Case for Developing America's Talent (U.S. Department of Education, U.S. DOE, 1993), according to the studies by Landrum, Katsiyannis, and DeWaard (1998). Based on an analysis of state and local advocacies for gifted education and their outcomes, Robinson and Moon (2003) observed that collaborative, persistent advocates, who are also knowledgeable about best practices in gifted education and political processes at both local and state levels, presence of a champion, solving skills and tools for practical problem-solving skills of advocates were required for positive outcomes of gifted education.

\section{Comparison of countries}

In a very exhaustive report, Mönks and Pflüger (2005) compared 21 countries in terms of their status of gifted education. The comparison parameters included school legislation, regulations and guidelines, specific provisions, giftedness identification criteria, the quality of the training provided and / or upgrading of the teachers and creating a network for exchanging experiences, research and professional care and counselling and priorities and expectations. The four levels of $0-3$ of the International Standard Classification of Education (ISCED-97) was used as the reference framework. The comparison variables applicable to the quality of gifted education were the specific provision items including having the entrance exams early, attending only the required classes, joining the higher grade students in their classes, training by groups for better improvements, workshops, having tie-ups with corporates or non-profit organisations, going beyond the set curriculum, having individual teachers, promoting individual studies, competition among the interns in schools, counselling through expert psychologists, summer camps, festivals, exhibition, school external competitions, performances and shows of artistic or other types, following higher ISCED level courses and special schools for gifted children. Many types of criteria for identification of gifted children were also being used. Training of teachers to enhance the quality of gifted education was a specific step. How well giftedness is recognised and differentiated, school curricular arrangements for gifted children were parts of the legislative and policy aspects used to compare the quality of gifted education in these countries.

\section{Specific suggestions for quality improvement of gifted education}

Policies and practices for quality improvement in gifted education should include specific interventions for advanced students as curricular differentiations between normal and gifted students is needed to develop the full potential of gifted children. On the other hand, convenience for accelerated education of gifted students which enable them to go through the stages of education faster than normal students is practiced in some countries. Understandably, development of creativity and innovation among gifted children should form an additional part of curriculum in the accelerated education programmes. These improvements can replace the old practice of selecting gifted students based on IQ tests and placing them on a separate stream of education. It may be difficult to implement if gifted students are placed in general stream (Plucker \& Callahan, 2014). From these and the points discussed above, it can be deduced that accelerated programmes within general education may be the best method of quality improvement of gifted education with minimum cost. Gifted children will find their own ways of developing their specific capabilities separately and if required guidance of experts can be provided.

\section{Specific suggestions for countries whose gifted education services need to be strengthened}

A set of improvements required in gifted education in USA were indicated from the works of VanTassel-Baska (2006). These include better systems of identifying gifted children in early stages and continued evaluation through their academic career; differentiation of education systems at a suitable level and suitable process; development of trained teachers to educate gifted children; active involvement of parents in the education process of gifted children; infrastructure, facilities ad funding issues and monitoring and evaluation plan. These observations are fairly comprehensive and may seem to suggest nothing has been done effectively on gifted education in USA. This is not correct.

The current status and need for improvement of gifted education in countries where such programmes exist, are discussed below, based on inputs from Wikipedia.

Australia has a public gifted education system which varies across its states. Tasmania, Capital Territory and Northern Territory do not seem to have gifted education programmes. It may be desirable to be implemented to have a uniform pattern across all states and union territories.

In Brazil, a special agency, Centre for Talent and Potential Development (CEDET), registers gifted students and the civil responsibility of this is given to the Association of Parents and Friends for Supporting Talent (ASPAT). It has limited jurisdiction within one municipality and its goals are limited to supplementary role. As an improvement, these agencies can be legalised and expanded to the whole country with expanded role of designing the curriculum and other activities for gifted children and training teachers.

In Canada also varied types of programmes are offered in Alberta, British Columbia and Ontario. There is need to unify them across the nation. Hong Kong follows the intelligence format of Howard Gardner and has gone a long 
way to implement the curricular system for gifted children in using this categorisation properly. The interconnections between levels of gifted education need to be more rationalised.

In India, National Talent Search examinations are conducted by NCERT (National Council of Education Research and Training) for class 9 students in two stages annually and those qualifying from the examination are given scholarships to pursue studies in any field they choose even up to doctorate level with adequate increases in the scholarship amounts as they progress from high school to doctorate. Specific gifted education programmes are conducted by Jnana Prabodhini Prashala, Pune for 80 students selected based on written tests and interviews and uses J P Guilford's intelligence. There is need for more such schools across the country. India has no specific political policy or strategy to develop talents in the population for internal use. Many brilliant academic achievers migrate to developed countries for advancement of education and career.

In Iran, National Organization for Development of Exceptional Talents (NODET, also known as SAMPAD) is in charge of gifted education at upper primary and high school levels. Students are selected through national entrance tests. Admission process is more selective in urban schools. College level science and maths are taught to these students by specially trained teachers. There is lack of focus on social sciences among students as well as the schools. There is need to reduce the urban-rural divide and more social science courses like management subjects in these schools.

Norway specialises only on music and dance talents in private sector in an assorted fashion. This leads to exclusion of children with other talents. The country needs to have a centralised public agency and expand gifted education in more subjects.

In Ireland there is a Centre for the Talented Youth of Ireland run in Dublin City University. There is need to expand its activities across the nation. There should also be more courses in different areas in cooperation with leading educational and research organisations in each area.

Republic of Korea, Gifted Education Promotion Law was passed in 2000 leading to the establishment of National Research Centre for Gifted and Talented Education (NRCGTE) in 2002 by Ministry of Education, Science, and Technology (MEST). This is a very good example of the seriousness attached by the state on gifted education. The Centre is managed by Korean Educational Development Institute (KEDI). Korean universities are involved in gifted education research to provide knowledge input for policies. Several schools across the country provide gifted education to talented students selected across the state. Teachers gave primary training in the country and advanced training abroad on skills of teaching gifted children.

In Singapore, Gifted Education Programme (GEP) is offered from primary levels since 1984. Only nine primary schools have implemented it so far. There is need to expand it to more schools and spread the test to select more students for the number of schools so increased.

In Slovakia, there is an APROGEN - Alternative Program for Gifted Education since 1988. Thus, gifted education is well separated. The progress so far had been limited. More efforts to expand gifted education is required.

In UK, schools are empowered to determine the best $5-10 \%$ of their students, which is a good practical approach. The terms "gifted" and "talented" have been differentiated to denote traditional academic subjects and creative arts and sports respectively. Gifted education programmes run by universities have seen opening and closing due to unsteady government policies and support. The government needs to have more stability through legal devices and empower at least some selected universities to research and develop their own gifted education programmes.

In USA, each state or districts decides about the mandatory nature of gifted education. The role of the state or district is only in determining the definition of giftedness and will not decide on the actual method of receiving gifted education services by these students. There is no federal regulation, but Federal Department of Education can offer advice. Problems of ethnic inequity have been observed among schools due to variations in procedures. As a way of improvement, the need for federal laws is indicated as in the case of special education. States can enact their own laws within the general framework of federal laws. There needs to be some regulatory institution at federal level with branches across the state to ensure fairness with respect to ethnic and socio-economic equity in offering gifted education by schools.

\section{Specific suggestions to countries that do not provide gifted education services}

The countries discussed above are not the only ones which implement gifted education. However, there are countries which do not have any gifted education programme. Cyprus and Japan have avoided gifted education programmes alleging elitist bias of giftedness. The refusal of Cyprus is also due to its perception of absence of any such need in the context of other socio-economic problems of its transition from colonial to independent state. In Japan, hard work is always held in high esteem which makes innate abilities an anathema. However, it promotes giftedness in an indirect way through measures to improve the country's STEM scores and ranking. Japan is one of the top STEM ranking country both in old system and the new index of comparison over the last 20 years (CEE, 2019). However, Japan has started with super science high schools in which students with super learning abilities are trained in special ways. This is 
inconsistent with its declared stand against elitist bias of gifted education. Japan wants to re-establish its lost dominance to China and India. Similar inconsistency also exists in the case of Austria . Not excluding any students based on elitism is a special character of education policies in Japan, Austria and Finland. Specific attempts were made in Korea to identify gifted children among socio-economically backward communities showing that gifted education can be developed without elitist bias. Poor quality design of gifted children identification and alignment of their education is evident in the case of UK. In Mexico, gifted education programmes are undertaken by private schools only although policies are set at national level. Private schools may define giftedness in their won fashion. In countries like Saudi Arabia, even without any formal gifted education policies or programmes, corporates may provide funds and other resources to promote programmes to develop gifted students like sponsorship or scholarships. In Finland, Nokia supports education and placement in their own units of talented students. Variations in gifted education policies and programmes among countries make it difficult to identify best practices. Countries like Austria and Russia, achievements in terms of Olympic medals or Nobel prizes are used as yardsticks to measure the effectiveness of gifted education programmes. Although these parameters cannot be used as yardsticks for best practices across countries, there is urgent need to identify best practices (Heuser, Wang, \& Shahid, 2017). Since Austria has shown a way to avoid elitist bias of giftedness, the countries, which do not have explicit gifted education programme can adapt Austria's method. Identification of best practices with measurement metrics can help these countries to use gifted education for their socio-economic development.

\section{Conclusions}

The concept of gifted education arises from the recognition that it is possible to differentiate exceptionally talented students and conventional teaching programmes and curricula are too slow for them. However, a stronger argument is given for retaining gifted students along with others, and those shine exceptionally well can be given addon programmes.

One of the issues hotly debated is equity. Perceptions that children of certain races have lower levels of intelligence, and therefore there are no gifted students among them arising from discriminatory identification of such children. This bias is illegal. However, Including them in gifted classes can create other issues. Underrepresentation of minorities means only a part of gifted education quality is improved, and the other part is completely neglected. This part-improvement leads to lowering of the national quality of gifted education compared to inclusive gifted education.

Instructional methods like problem-solving and inquiry-based learning are very useful to promote giftedness in mixed abilities classes. Integrative frameworks like ICAP and CDL are shown to ensure quality in gifted education.

\section{Limitations}

All papers were not directly on the quality of gifted education. Papers with exact titles or only containing this topic were very rare. However, many factors related to the quality of gifted education have been discussed in many papers, and these were very informative for this type of review. 


\section{Appendix - PRISMA Diagram}
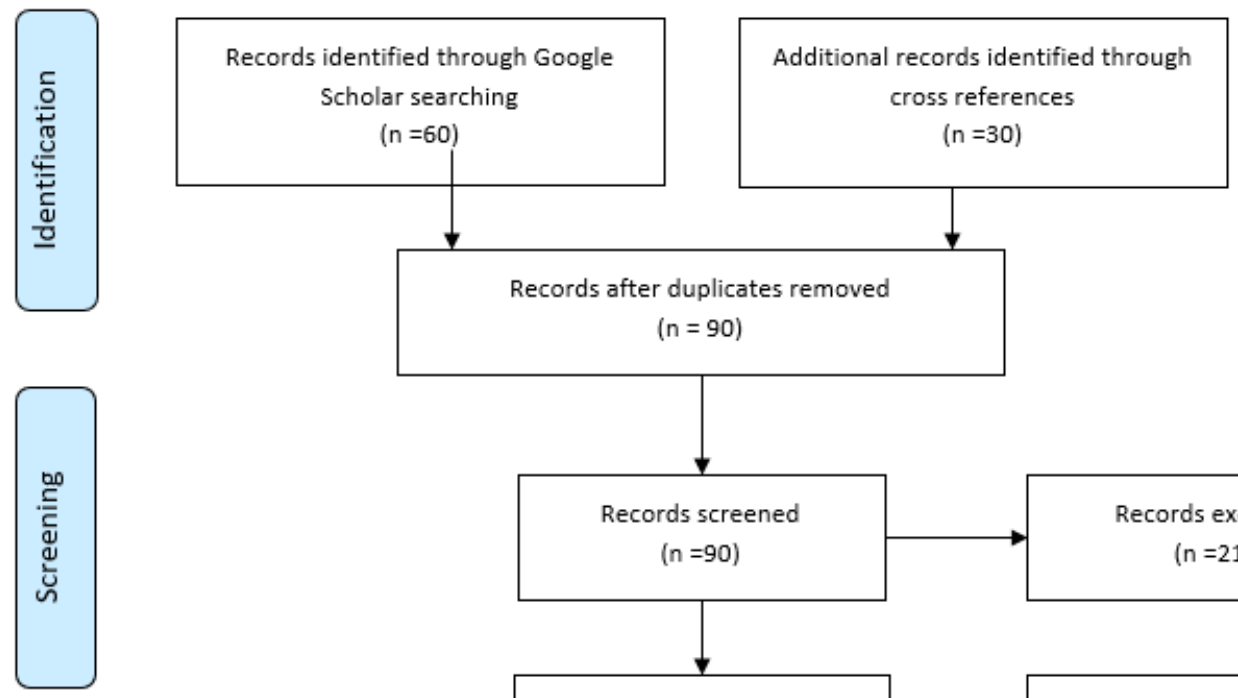

Records after duplicates removed

$$
(n=90)
$$
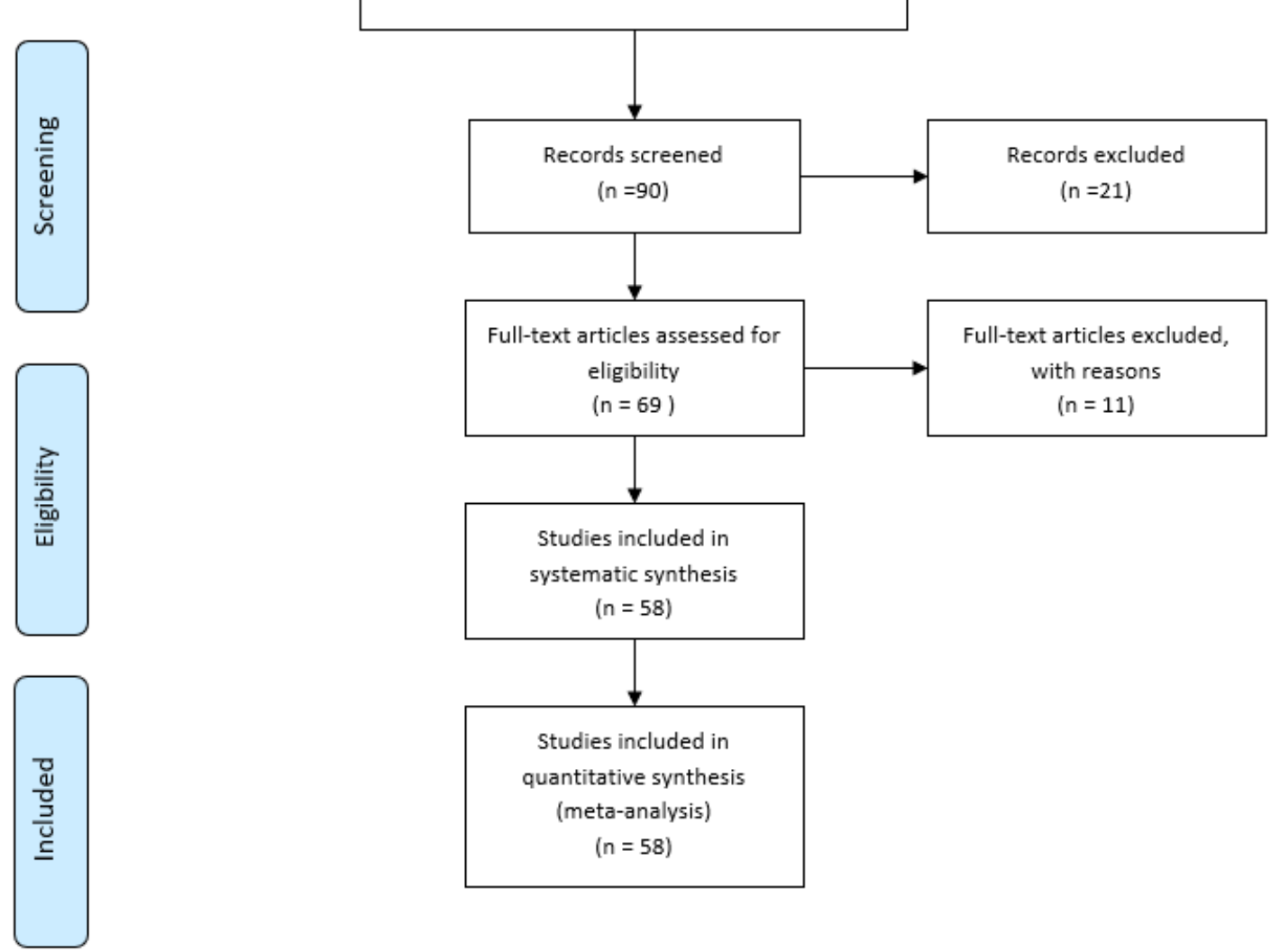

Figure 1. PRISMA Diagram

\section{REFERENCES}

[1] Almeida, L. S., Prieto, M. D., Ferreira, A. I., Bermejo, M. R., Ferrando, M., \& Ferrándiz, C. (2010). Intelligence assessment: Gardner multiple intelligence theory as an alternative. Learning and Individual Differences, 20(3), 225-230. doi:10.1016/j.lindif.2009.12.010

[2] Bainbridge, C. (2019, November 27). How to identify a gifted child. Retrieved May 5, 2020, from Very well family: https://www.verywellfamily.com/what-is-a-gifted-child-14 49130

[3] Baker, B. D., \& Friedman-Nimz, R. (2004). State Policies and Equal Opportunity: The Example of Gifted Education. Educational Evaluation and Policy Analysis, 26(1), 39-64. doi:/10.3102/01623737026001039

[4] Baker, B. D., \& McIntire, J. (2003). Evaluating state funding for gifted education programs. Roeper Review, 25(4), 173-179. doi:10.1080/02783190309554225

[5] Boettger, E. R.-H. (2015). Gifted education in various countries of Europe. Slavonic pedagogical studies journal, 4, 158-171. doi:10.18355/PG.2015.4.2.158-171

[6] Callahan, C. M. (1996). A critical self-study of gifted education: Healthy practice, necessary evil, or sedition? Talents and Gifts, 19(2), 148-163. doi:10.1177/0162353296 01900203

[7] Chae, Y. (2019). The model of the Online Gifted Education Support System: By Analyzing FGI and Delphi Surveys. In G. Marks (Ed.), Proceedings of Global Learn 2019-Global Conference on Learning and Technology (pp. 184-190). Princeton-Mercer, New Jersey: Association for the Advancement of Computing in Education (AACE). Retrieved May 18, 2020, from https://www.learntechlib.org /p/210304/

[8] Chen, J., Yun Dai, D., \& Zhou, Y. (2013). Enable, enhance, and transform: How technology use can improve gifted 
education. Roeper Review, 35(3), 166-176. doi:10.1080/02783193.2013.794892

[9] Clarenbach, J. (2007). All Gifted Is Local. School Administrator, 64(2), 16-21. Retrieved May 17, 2020, from https://eric.ed.gov/?id=EJ757417

[10] Dinçer, S. (2019). Investigation of the Gifted Education Self-Effecacy of Teachers Work with Gifted Students. Üstün Zekalılar Ĕgitimi ve Yaratıcılık Dergisi, 6(3), 167-174. Retrieved May 18, 2020, from https://s3.amazonaws.com/a cademia.edu.documents/62912356/JGEDC-6-3-1-6347382 0200411-80824-mg0lq8.pdf?response-content-disposition $=\mathrm{i}$ nline $\% 3 \mathrm{~B} \% 20$ filename $\% 3$ DInvestigation of the Gifted E ducation_Se.pdf\&X-Amz-Algorithm=AWS4-HMAC-SHA $256 \& X-\bar{A} m z-C r e d e n t i a l=A S I A T U S$

[11] Dracup, T. (2003). An outline of England's strategy for gifted and talented education. Gifted Education International, 17(2), 112-119. doi:10.1177/0261429403017 00203

[12] Ford, D. Y. (1998). The underrepresentation of minority students in gifted education: Problems and promises in recruitment and retention. The Journal of Special Education, 32(1), 4-14. doi:10.1177/002246699803200102

[13] Ford, D. Y. (2014). Segregation and the underrepresentation of Blacks and Hispanics in gifted education: Social inequality and deficit paradigms. Roeper Review, 36(3), 143-154. doi:10.1080/02783193.2014.919563

[14] Ford, D. Y., \& King Jr, R. A. (2014). No Blacks Allowed: Segregated Gifted Education in the Context of Brown v. Board of Education. Journal of Negro Education, 83(3), 300-310. Retrieved May 17, 2020, from https://www.researchgate.net/profile/Donna_Ford5/publicat ion/323824928_No_Blacks_Allowed_Segregated_Gifted_E ducation in the Context of Brown $\mathrm{v}$ Board of Educatio $\mathrm{n} /$ links $/ 5 \mathrm{aac} 74 \mathrm{~b} \overline{\mathrm{fa}} 6 \mathrm{fdcc} 1 \mathrm{bc} 0 \overline{\mathrm{b}} 8 \mathrm{da} 9 \mathrm{e} / \bar{N}_{\mathrm{No}}-\mathrm{Blacks}-\mathrm{All}$ lowed-Se gregated-Gifted-Education-in-the-Context-o

[15] Ford, D. Y., Grantham, T., \& Whitin, G. W. (2008). Culturally and Linguistically Diverse Students in Gifted Education: Recruitment and Retention Issues. Exceptional Children, 74(3), 289-207. doi:10.1177/0014402908074003 02

[16] Ford, D. Y., Harris III, J. J., Tyson, C. A., \& Trotman, M. F. (2001). Beyond deficit thinking: Providing access for gifted African American students. Roeper Review, 24(2), 52-58. doi:10.1080/02783190209554129

[17] Ford, D. Y., Wright, B. L., Washington, A., \& Henfield, M. S. (2016). Access and Equity Denied: Key Theories for School Psychologists to Consider When Assessing Black and Hispanic Students for Gifted Education. School Psychology Forum: Research in Practice, 10(3), 265-277. Retrieved May 17, 2020, fromhttps://www.researchgate.net /profile/Ahmad Washington/publication/312121099 Acces $\mathrm{s}$ and Equity Denied Key Theories for School Psychol ogists_to_Consider_When_Asssessing_Black_and_Hispanic Students for_Gifted_Education/links/586ffdc $70 \overline{8}$ ae 8 fce 49 $\overline{1}$ def5f/Access-an

[18] Gallagher, J. J. (1996). A Critique of Critiques of Gifted Education. Journal for the Education of the Gifted, 19(2), 234-249. doi:10.1177/016235329601900208

[19] Gallagher, J. J. (2004). No child left behind and gifted education. Roeper Review, 26(3), 121-123.doi:10.1080/027 83190409554255

[20] Grantham, T. C., \& Ford, D. Y. (1998). Principal instructional leadership can reverse the under-representation of black students in gifted education. NASSP Bulletin, 82(595), 101-109. doi:10.1177/019263659808259512

[21] Hockett, J. A. (2009). Curriculum for highly able learners that conforms to general education and gifted education quality indicators. Journal for the Education of the Gifted, 32(3), 394-440. doi:10.4219/jeg-2009-857

[22] Hudson, K. (2020). Differences between Gifted and Non-Gifted Students' Perceptions of Advanced International Certificate of Education Course Quality. Liberty University. Retrieved May 18, 2020, from https://digitalcommons.libert y.edu $/$ cgi/viewcontent.cgi? article $=3390 \&=\&$ context $=$ doctor al\& $=\&$ sei-redir $=1 \&$ referer $=\mathrm{https} \% 253 \mathrm{~A} \% 252 \mathrm{~F} \% 252 \mathrm{Fscho}$ lar.google.com $\% 252$ Fscholar $\% 253 \mathrm{Fas}$ ylo $\% 253 \mathrm{D} 2016 \% 2$ $526 \mathrm{q} \% 253$ Dquality $\% 252$ Bof $\% 252$ Bgifted $\% 252$ Beducation $\% 2526 \mathrm{hl} \% 253$ Den\%2526as sdt\%

[23] Jarvis, J. M., \& Henderson, L. (2014). Defining a coordinated approach to gifted education. Australasian Journal of Gifted Education, 23(1), 5-14. Retrieved May 17, 2020, from https://www.researchgate.net/profile/Jane Jarvi s/publication/307928828_Defining_a_coordinated_approac $\mathrm{h}$ to gifted education/links/57d22 $\overline{4}$ be 08 ae $6399 \mathrm{a} 38 \mathrm{~b} 8 \mathrm{c} 92 /$ Defining-a-coordinated-approach-to-gifted-education.pdf

[24] Jolly, J. L. (2014). Building Gifted Education: One State at a Time. Gifted Child Today, 37(4), 258-260. doi:10.1177/1076217514544031

[25] Jolly, J. L., \& Robins, J. H. (2016). After the Marland Report: Four Decades of Progress? Journal for the Education of the Gifted, 39(2), 132-150. doi:10.1177/0162353216640937

[26] Landrum, M. S., Katsiyannis, A., \& DeWaard, J. (1998). A national survey of current legislative and policy trends in gifted education: Life after the National Excellence report. Journal for the Education of the Gifted, 21(3), 352-371. doi:10.1177/016235329802100306

[27] Lapan, S. D. (1989). Guidelines for developing and evaluating gifted programs. Roeper Review, 11(3), 167-169. doi:10.1080/02783198909553197

[28] Lewis, J. D., Cruzeiro, P. A., \& Hall, C. A. (2007). Impact of two elementary school principals' leadership on gifted educational in their Buildings. Gifted Child Today, 30(2), 56-62. Retrieved May 17, 2020, from https://files.eric.ed.gov/fulltext/EJ756555.pdf

[29] Lo, C. O., \& Porath, M. (2017). Paradigm shifts in gifted education: An examination vis-a-vis its historical situatedness and pedagogical sensibilities. Gifted Child Quarterly, 61(4), 343-360. doi:10.1177/0016986217722840

[30] Long, L. C., Barnett, K., \& Rogers, K. B. (2015). Exploring the relationship between principal, policy, and gifted program scope and quality. Journal for the Education of the Gifted, 38(2), 118-140. doi:10.1177/0162353215578279

[31] Marland, S. P. (1972). Education of the gifted and talented Report to the Congress of the United States by the US Commissioner of Education. US Government Printing Office, Washington. Retrieved May 4, 2020, from https://www.valdosta.edu/colleges/education/human-servic 
es/document $\% 20 /$ marland-report.pdf

[32] McGlonn-Nelson, K. (2005). Looking outward: Exploring the intersections of sociocultural theory and gifted education. Journal of Secondary Gifted Education, 17(1), 48-55. Retrieved May 18, 2020, from https://files.eric.ed.gov/fullte $\mathrm{xt} / \mathrm{EJ} 746045 . \mathrm{pdf}$

[33] Mönks, F. J., \& P. R. (2005). Gifted education in 21 European countries: Inventory and perspective. Nijmegen: Radboud University Nijmegen. Retrieved May 18, 2020, from

http://193.2.74.246/fileadmin/Datoteke/CRSN/branje/Gifte d Education in 21 European Countries Inventory and P erspective_ 2005 _.

[34] Munro, J. K. (2015). Scenario problem solving: A measure of the quality of gifted students' thinking. Australasian Journal of Gifted Education, 24(1), 23. doi:10.21505/ajge.2015.0004

[35] NAGC. (2019, November 7). A Definition of Giftedness that Guides Best Practice. Retrieved May 5, 2020, from National Association for Gifted Children: https://www.nagc.org/sites /default/files/Position\%20Statement/Definition\%20of\%20G iftedness $\% 20 \% 282019 \% 29 . p d f$

[36] Neber, H. (2019). Gifted Education: an opportunity for improving the quality of teaching and learning in classrooms. University of Duisburg-Essen. Retrieved May 18, 2020, from https://rcepunesco.ae/en/KnowledgeCorner/ WorkingPapers/WorkingPapers/Policies\%20for\%20Identif ying\%20and $\% 20$ Nurturing\%20Gifted $\% 20$ and $\% 20$ Talented \%20Students\%20Policy\%20Dialogue\%20-\%20Fourth\%20 Paper.pdf

[37] Newman, J., Gregg, M., \& Dantzler, J. (2009). Summer Enrichment Workshop (SEW): A Quality Component of The University of Alabama's Gifted Education Preservice Training Program. Roeper Review, 31(3), 170-184. doi:10.1080/02783190902993995

[38] OxfordLearning. (2015, September 18). What's The Score? Problems With IQ Tests For Kids. Retrieved May 5, 2020, from Oxford Learning:https://www.oxfordlearning.com/wh ats-the-score-problems-with-iq-tests-for-kids/

[39] Parr, J., \& Stevens, T. (2019). Challenges of Equity and Discrimination in the Education of Gifted Children. In W. e. Leal Filho (Ed.), Quality Education (Vol. Encyclopedia of the UN Sustainable Development Goals, p. 13 pp). Springer Nature Switzerland AG. doi:10.1007/978-3-319-69902-8_2 $1-1$

[40] Purcell, J. H., Burns, D. E., Tomlinson, C. A., Imbeau, M. B., \& Martin, J. L. (2002). Bridging the gap: A tool and technique to analyze and evaluate gifted education curricular units. Gifted Child Quarterly, 46(4), 306-321. doi:10.1177/001698620204600407

[41] PurdueEngineering. (2020). Who are "gifted and talented" students? Retrieved May 4, 2020, from Purdue University: https://engineering.purdue.edu/ andy/challenge/LSCgifted/ definition.htm

[42] Riley, T. L., \& Karnes, F. A. (1993). The Tools for Success for Concerned Citizens: Shaping Public Policy in Gifted Education. Gifted Child Today (GCT), 16(2), 23-25. doi:10.1177/107621759301600209

[43] Robinson, A., \& Moon, S. M. (2003). A national study of local and state advocacy in gifted education. Gifted Child Quarterly, 47(1), 8-25. doi:10.1177/001698620304700103

[44] Roy, P. (2017). Gifted education in India. Cogent Education, 4(1), 1332815. Retrieved May 16, 2020, doi: 10.1080/2331186X.2017.1332815

[45] Sapon-Shevin, M. (1996). Beyond gifted education: Building a shared agenda for school reform. Talents and Gifts, 19(2), 194-214. doi:10.1177/016235329601900206

[46] Shaughnessy, M. F., \& Persson, R. S. (2009). Observed trends and needed trends in gifted education. In L. V. Shavinina (Ed.), International handbook on giftedness (pp. 1285-1291). Springer, Dordrecht. doi:10.1007/978-1-40206162-2 67

[47] Stoltz, T., Piske, F. H., de Fátima Quintal de Freitas, M., D'Aroz, M. S., \& Machado, J. M. (2015). Creativity in Gifted Education: Contributions from Vygotsky and Piaget. Creative Education , 6, 64-70. doi:10.4236/ce.2015.61005

[48] Subotnik, R. F., Olszewski-Kubilius, P., \& C, W. F. (2011). Rethinking giftedness and gifted education: A proposed direction forward based on psychological science. Psychological science in the public interest, 12(1), 3-54. doi:10.1177/1529100611418056

[49] Tomlinson, C. A. (1997). Good teaching for one and all: Does gifted education have an instructional identity? Journal for the Education of the Gifted, 20(2), 155-174. doi:10.1177/016235329602000201

[50] Tomlinson, C. A. (2005). Quality curriculum and instruction for highly able students. Theory into practice, 44(2), 160-166. doi:10.1207/s15430421tip4402 10

[51] Tomlinson, C. A., \& Callahan, C. M. (1992). Contributions of gifted education to general education in a time of change. Gifted Child Quarterly, 36(4), 183-189. doi:10.1177/00169 8629203600403

[52] VanTassel-Baska, J., \& Brown, E. F. (2007). Toward Best Practice: An Analysis of the Efficacy of Curriculum Models in Gifted Education. Gifted Child Quarterly, 51(4), 342-358. doi:10.1177/0016986207306323

[53] VanTassel-Baska, J., Zuo, L., Avery, L. D., \& Little, C. A. (2002). A curriculum study of gifted-student learning in the language arts. Gifted Child Quarterly, 46(1), 30-44. doi:10.1177/001698620204600104

[54] Ziegler, A., \& Phillipson, S. N. (2012). Towards a systemic theory of gifted education. High Ability Studies, 23(1), 3-30. doi:10.1080/13598139.2012.679085

[55] CEE. (2019, October 15). New Index of STEM education. Retrieved July 17, 2020, from Centre for Excellence in Education:

https://www.cee.org/events/new-index-excellence-stem-edu cation

[56] Heuser, B. L., Wang, K., \& Shahid, S. (2017). Global Dimensions of Gifted and Talented Education: The Influence of National Perceptions on Policies and Practices. Global Education Review, 4(1), 4-21. Retrieved July 17, 2020, from https://files.eric.ed.gov/fulltext/EJ1137994.pdf

[57] Plucker, J. A., \& Callahan, C. M. (2014). Research on giftedness and gifted education: Status of the field and considerations for the future. Exceptional Children, 80(4), 
390-406. doi:10.1177/0014402914527244

[58] VanTassel-Baska, J. (2006). A content analysis of evaluation findings across 20 gifted programs: A clarion call for enhanced gifted program development. Gifted Child Quarterly, 50(3), 199-215. doi:10.1177/0016986206050003 02 